\title{
Effect of water temperature on occurrence of Edwardsiella tarda in olive flounder Paralichthys olivaceus farms in Jeju island, South Korea
}

Juri Yoo

Fishcare laboratory

Sori Han

Fishcare laboratory

Jimin Hong

Fishcare laboratory

Bo-Kwang Kang

Fishcare laboratory

Mai Thi Phuong

Fishcare laboratory

Woo-Jai Lee

Blugen Korea

Hetron Mweemba Munang'andu

Norweagian University of Life Sciences

Sung-Hyun Kim ( $\nabla$ fishcare@outlook.kr)

https://orcid.org/0000-0003-0064-5848

Research note

Keywords: Edwardsiella tarda, Olive flounder, Infection rate, Water temperature, Latent period.

Posted Date: July 9th, 2019

DOI: https://doi.org/10.21203/rs.2.11137/v1

License: (c) (1) This work is licensed under a Creative Commons Attribution 4.0 International License. Read Full License 


\section{Abstract}

Objective: Edwardsiellosis is an important disease associated with high economic losses in aquaculture. In the present study we wanted to determine whether occurrence of Edwardsiella tarda infections in Olive flounder (Paralichthys olivaceus) correspond with changes in water temperature on fish farms in Jeju island, South Korea. Results: In 2017, the number of cases were highest in August and September reaching up to $70 \%$ of the sampled fish when the average monthly water temperature was highest at $21.7^{\circ} \mathrm{C}$. The number of cases declined to $<5 \%$ during the cold months of January to March when the mean monthly water temperatures were lowest varying between $15.6^{\circ} \mathrm{C}$ and $16.4^{\circ} \mathrm{C}$ in 2017 . However, the number of cases in 2018 where lower than in 2017 despite the average annual temperature for both years being equal at $18.2^{\circ} \mathrm{C}$. Interestingly, the number of cases observed in the first three months of 2019 corresponded with cases observed in 2017 during the first three months when the average water monthly temperature was $16.4^{\circ} \mathrm{C}$ and $15.2^{\circ} \mathrm{C}$. Data presented herein could be useful in understanding the effect of water temperature on occurrence of $\mathrm{E}$. tarda infection leading to developing intervention control measures against $E$. tarda infections in aquaculture.

\section{Background}

In 2018, Jeju island produced 22,169 tons of cultured olive flounder (Paralichthys olivaceus) accounting for $59.4 \%$ of the total fish production in South Korea (KOSIS, 2019). As the scale of the flounder farm continues to increase, occurrence of various diseases due to high stocking density and intensive management aimed at mass production has also increased (Oh et al., 1998). Among the bacterial diseases reported, Streptococcus sp., Edwardsiella tarda, and Vibrio sp. are the most common (Lee and Ha, 1991; Oh et al., 1998; Heo et al., 2001; Kim et al., 2001; Kim and Kim, 2003; Baeck et al., 2006). E. tarda is one of the major infectious diseases in aquaculture, which is also pathogenic to a variety of animals(Austin and Austin, 1993) and humans(Janda et al., 1993).

E. tarda is a gram-negative bacterium that is photogenic and photosynthetic known to infect fish throughout the year, but it is usually highly contagious in high temperature or poor water quality (Woo et al., 2011; Sakai et al., 1994; Rashid et al., 1994). It is highly pathogenicity when the temperature is between $20^{\circ} \mathrm{C}$ and $25^{\circ} \mathrm{C}$ than in low temperature below $15^{\circ} \mathrm{C}$ (Zheng et al., 2004). Typical symptoms of fish infected by $E$. tarda include necrotizing small skin lesions, abdominal distractions caused by ascites, internal degeneration, kidney hypertrophy, internal organ tumors and liver hypertrophy(Plumb,1999; Satoshi and Nobuhiro, 2000).

The present study intend to determine occurrence of $E$. tarda cases in olive flounder in relation to changes in temperature in aquaculture on Jeju Island in South Korea and to provide baseline data for the development of intervention programs aimed at reducing the prevalence of $E$. tarda, a major pathogen of olive flounder.

\section{Methods}


A total of 13, 16 and 16 fish farms were sampled in 2017, 2018 and 2019 in Jeju island, respectively (Fig. 1). Five to six fish were randomly selected and collected from each fish farm leading to a total 80 96 fishes per week. At the same time, fish were collected from each fish farm in tanks that had the highest mortality. Clinical and pathological examination was carried out on olive flounder that had signs of disease infection on the farms. Culture water temperature was measured from 9:30 a.m. to 10:30 a.m. every week using a water temperature thermometer at each fish farm. A total of 16 farms were included in the study of which four consisted of four sea water farms while 14 farms comprised of seawater mixed with salty underground water. The location of the farms on Jeju Island are shown in Figure 1. Samples were collected for the period of 27 months as a monitoring program for $E$. tarda and temperature was recorded monthly for the same period.

Symptoms observed from diseased fish on the farms sampled included abdominal distention, hernia, liver nodules, kidney and hypertrophy. Bacteria isolation and culture was carried out using liver samples on basic media followed by culture on Salmonella-Shigella(SS) selective medium. On the SS medium, the bacteria species identified as $E$. tarda produced colonies after incubation at $30^{\circ} \mathrm{C}$ for 48 hours. Colonies showing characteristic black centered were considered to be $E$. tarda. Thereafter, the colonies were subjected to Polymerase chain reaction (PCR) using primers specific for $E$. tarda by the method described Han et al (Han et al., 2017) for bacteria identification.

The detection trends were analyzed as a percentage(\%) of $E$. tarda cases detected in proportion to the total number of samples collected on the fish farms. The water temperature of fish farms that only use salty underground water for fish culture in which water temperature was maintained at the same level throughout the year were excluded from the study. This is mainly because data from these farms showed no changes of water temperature that could influence changes on $E$. tarda occurrence on fish farms. Hence, data from these farms was outside the main focus of this study.

\section{Results And Discussion}

The western part of Jeju Island mainly uses natural sea water for the culture of olive flounder on the fish farms while the southern and eastern areas use a combination of natural and salty underground water to minimize water temperature changes. Since salty underground water maintains a certain level of water temperature at $17^{\circ} \mathrm{C}$ to $19^{\circ} \mathrm{C}$ throughout the year, the water temperature on fish farms in Jeju Island has a narrow range of water temperature compared to the cage culture farms that cultivate in littoral sea.

\section{Water temperature on fish farms used for culture of Olive flounder}

Water temperature rises or falls due to the effects of natural sea water and the annual average water temperature in 2017 and 2018 was $18.2^{\circ} \mathrm{C}$ (Table 1, Fig. 2). The average monthly temperature in 2017 was lowest in February at $15.2^{\circ} \mathrm{C}$, and the highest was $22.3^{\circ} \mathrm{C}$ in July, but the average monthly water temperature on the fish farms was highest in August. In 2018 , the lowest daily temperature was $14.7^{\circ} \mathrm{C}$ in February, also the lowest average monthly temperature was in February at $14.9^{\circ} \mathrm{C}$ while the highest daily temperature was in August at $23.4^{\circ} \mathrm{C}$, and the lowest monthly temperature was $22.4^{\circ} \mathrm{C}$ also in August. 
Water temperature in 2019 was only measured from January to March and, as such, there is no annual average water temperature analysis due to the shorter duration of measurement. However, the monthly average water temperature was in the range of 15.5 to $16.6^{\circ} \mathrm{C}$ for the period March to January 2019. Overall, average monthly water temperature measured at the olive flounder farms showed a cyclic pattern of temperatures being high in the months of July to September while the period February and March had the lowest mean monthly temperatures as shown for 2017 and 2018 in Table 1. In general, there was no difference in mean annual temperatures for 2017 and 2018.

\section{Detection of Edwardsiella tarda on olive flounder farms}

Based on isolation on selective media, mainly SS agar, and molecular diagnosis using PCR, E. tarda was detected for most of the study period of which the detection rate fluctuated over a wide range from $0 \%$ to $78 \%$ of the total number of sampled at each time point (Fig. 2). The average $E$. tarda detection rate for the entire 27 months January 2017 to March 2019 study period showed that $E$. tarda detection was higher in 2017 than in 2018. Data in Figure-2 shows that presence of $E$. tarda on olive farms corresponded with changes in monthly water temperature. In 2017 , the highest incidence of $E$. tarda reached up to $78 \%$ during the period July to August when water temperatures were also high with an average of $21^{\circ} \mathrm{C}$. The prevalence of $E$. tarda remained high while water temperatures were moderately high in the subsequent months September and October as the temperature began to decline from $21^{\circ} \mathrm{C}$ to $19.9^{\circ} \mathrm{C}$ in 2017 . The decrease in water temperature observed in November and December 2017 continued to $18.3^{\circ} \mathrm{C}$ and $17.7^{\circ} \mathrm{C}$, respectively, corresponded with the decrease in detection of $E$. tarda on olive flounder farms. These observations are in line with Zheng et al (Zheng et al., 2004) who showed that occurence of $E$. tarda was high when water temperature was between $20^{\circ} \mathrm{C}$ and $25^{\circ} \mathrm{C}$ than when the temperature was below $15^{\circ} \mathrm{C}$ being in line with our observations that more than $70 \%$ cases occured in August, 2017 when the monthly average temperatures reached its peak at $21.7^{\circ} \mathrm{C}$.

At the start of 2018, the number of $E$. tarda cases continued to decline further to $<5 \%$ in the first and second quarter corresponding with the continued decrease in water temperature to $15.3^{\circ} \mathrm{C}$ and $14.9^{\circ} \mathrm{C}$, respectively. The number of cases started to increase in August 2018 with a slight decrease in the last quarter of October and beginning of November and continued being higher in November and December 2018. Generally, the overall number of cases observed in 2018 were lower than the number of cases observed during the previous year in 2017. Although we did not investigate the factors that could have led to this decline, it is likely that fish previously exposed to the same bacteria in 2017 were carried into 2018 and that these fish could have developed some immune protection against $E$. tarda due to exposure in 2017. Hence, immune protection developed due to exposure in 2017 could have reduced bacteria replication on subsequent exposure leading to a reduced incidence in 2018 compared to the previous year. However, these is need for further studies to consolidate the notion that previous exposure to $E$. tarda could be contributing to reducing the number of cases in subsequent years.

It is interesting to note that the monthly average water temperature on olive farms for January, February and March in 2019 was $16.5^{\circ} \mathrm{C}, 16^{\circ} \mathrm{C}$ and $15.9^{\circ} \mathrm{C}$, while the $E$. tarda detection rate was $20 \%, 19 \%$ and $12 \%$, 
which shows a similar trend for observations made during the period January to March 2017. It could be that fish were equally susceptible at the beginning of 2017 and 2019 although the host factors underlying this trend were not investigated. On the hand, it could also be that the bacteria presence in the environments was equally high at the beginning of 2017 and 2019. This could also imply that the years of high E. tarda prevalence as seen in 2017 are followed by years of low prevalence as in 2018, which could be due to increased immune protection from previous exposure to the bacteria. Once, the immune protection from previous exposure wanes off or introduction of new fish on the fish farms occurs, the susceptibility to $E$. tarda also increases as would be the case with increased cases at the start of 2019 compared to the previous year. However, there is need for detailed investigation to understand the underlying factors regulating the cyclic pattern of E. tarda occurrence on Jeju Island. Nonetheless, data from this study could to be useful developing intervention programs for the control of $E$. tarda on olive flounder farms in Jeju island.

\section{Major limitations}

One of the major limitations in this study is that we did not investigate whether previous exposure to Edwardseillosis could have produced immune protection in fish leading to reduced number of cases in subsequent years. Another limitation is that there was no culture of the bacteria from water samples to determine its prevalence in the environment so as to determine whether there was increased presence of the bacteria during the warm months of July to September and reducing during the cold months of January to March in the environment. Future studies should address these limitations in order to determine whether there is a corresponding increase of bacteria in water during the warm months of July to September declining during the cold months of January to March corresponding with infection rates in olive flounder. In addition, it would be useful to determine whether host immune response to previous infection reduces susceptibility in subsequent exposure. This would help determine the cyclic trend in which the years with high incidence of $E$. tarda cases are followed by years of reduced incidence on the number of $E$. tarda cases detected on fish farms.

\section{Declarations}

\section{Acknowledgements}

We thank for all participants in this study.

\section{Ethics approval and consent to participate}

All the experimental procedures in this study followed the Norwegian Ministry of Agriculture and Food's definition of competence accomplished at Norwegian Veterinary Science School's "FELASA C" level, laboratory animal science for researchers (course director section for experimental biomedicine Norwegian school of veterinary science professor J R Needham, course reference 12-07). All of the samples were collected by under permission from fish farms that contracted with fishcare laboratory and samples were killed ethically by cutting spinal cord after narcotized with anaesthetic MS-222. 
Availability of data and material

All data generated or analysed during this study are included in this published article.

\section{Funding}

The result of this study which is disease monitoring data was made from subproject "Localization and production of healthy olive flounder juveniles" of the Golden Seed project (213008-05-2-SB220). Golden Seed project was supported from the Korea Institute of Agriculture, Food and Rural Affairs.

\section{Consent for publication}

Not applicable

\section{Competing interests}

The authors declare that they have no competing interests.

\section{Author's contributions}

JY: Study design, led the data analysis and interpretation and wrote the manuscript. SH: study implementation and interpretation of results $\mathrm{JH}$ : study implementation. BK: study implementation. MP: study implementation. WL: conceptualized and contributed to writing and editing. HM: conceptualized and contributed to writing and editing. SK: conceptualized and designed the study and contributed to writing and editing. All authors critically reviewed the manuscript. All authors read and approved the final manuscript.

\section{References}

Austin B and DA Austin. Enterobacteriaceae representatives. In Bacterial fish pathogens: Disease in farmed and wild fish, 2nd ed., Ellis Horwood Ltd., Chichester; 1993. p. 188-226.

Han SR, Han HS, Evensen $\mathrm{O}$ and Kim SH. PCR-based identification of Pseudomonas fluorescens in diseased olive flounder, Paralichthys olivaceus, in Jeju Island, South Korea. J Fish Pathol. 2017;30:67-70.

Janda JM and Abbott SL. Infections associated with the genus Edwardsiella: the role of Edwardsiella tarda in human disease. Clin Infect Dis. 1993;17:742-748.

KOSIS (Korean Statistical Information Service). Survey On the Status of Fish Culture. 2018. http://kosis.kr/statHtml/statHtml.do?orgld=101\&tblld=DT_1EW0004\&conn_path=I3. Accessed 5 April 2019.

Oh SP, Kim DH, Lee JJ and Lee CH. Bacterial diseases in flounder farms of Cheju Island, J Fish Pathol. 1998;11:23-27. 
Plumb JA. Edwardsiella Septicaemias, Fish diseases and disorders, volume 3; viral, bacterial, and fungal infections, vol. 3, Woo PTK, Bruno DW, Oxon, UK: CAB International. 1999. p. 479-521.

Rashid MM, Kazumitsu H, Toshihiro N and Kiyokuni M. An ecological study on Edwardsiella tarda in flounder farms. Fish Pathol. 1994;29:221-7.

Sakai M, Atsuta S and Kobayashi M. Survival of fish pathogen Edwardsiella tarda in sea water and fresh water. Bull Eur Assoc Fish Pathol. 1994;14:188-190.

Satoshi M and Nobuhiro M. Infection with Edwardsiella tarda causes hypertrophy of liver cells in the Japanese flounder Paralichthys olivaceus. Dis Aquat Org. 2000;42:227-231.

Woo PT, Leatherland JF and Bruno DW. Edwardsiella septicaemias: Fish diseases and disorders, In Plumb, JA. New York, USA: CABI; 2011;3: p. 479-521.

Zheng Dahai, Mai K, Liu S, Cao L, Liufu Z, Xu W, Tan B and Zhang W. Effect of temperature and salinity on virulence of Edwardsiella tarda to Japanese flounder, Paralichthys olivaceus (Temminck et Schlegel). Aquac Res. 2004;35:494-500.

\section{Tables}

Table 1 Monthly average water temperature $\left({ }^{\circ} \mathrm{C}\right)$ on flounder farms

\begin{tabular}{cccc}
\hline Year & 2017 & 2018 & 2019 \\
\hline Jan & 16.4 & 15.3 & 16.5 \\
\hline Feb & 15.5 & 14.9 & 16.0 \\
Mar & 15.6 & 15.2 & 15.9 \\
\hline Apr & 16.2 & 16.2 & - \\
May & 16.6 & 17.1 & - \\
\hline Jun & 18.3 & 19.0 & - \\
\hline Jul & 21.0 & 20.6 & - \\
\hline Aug & 21.7 & 22.4 & - \\
\hline Sep & 21.0 & 21.0 & - \\
\hline Oct & 19.9 & 19.8 & - \\
\hline Nov & 18.9 & 19.2 & - \\
\hline Dec & 17.3 & 18.3 & $16.1( \pm 0.29)$ \\
\hline Mean $( \pm S D)$ & $18.2( \pm 2.27)$ & $18.2( \pm 2.49)$ &
\end{tabular}

$-:$ not measured

\section{Figures}




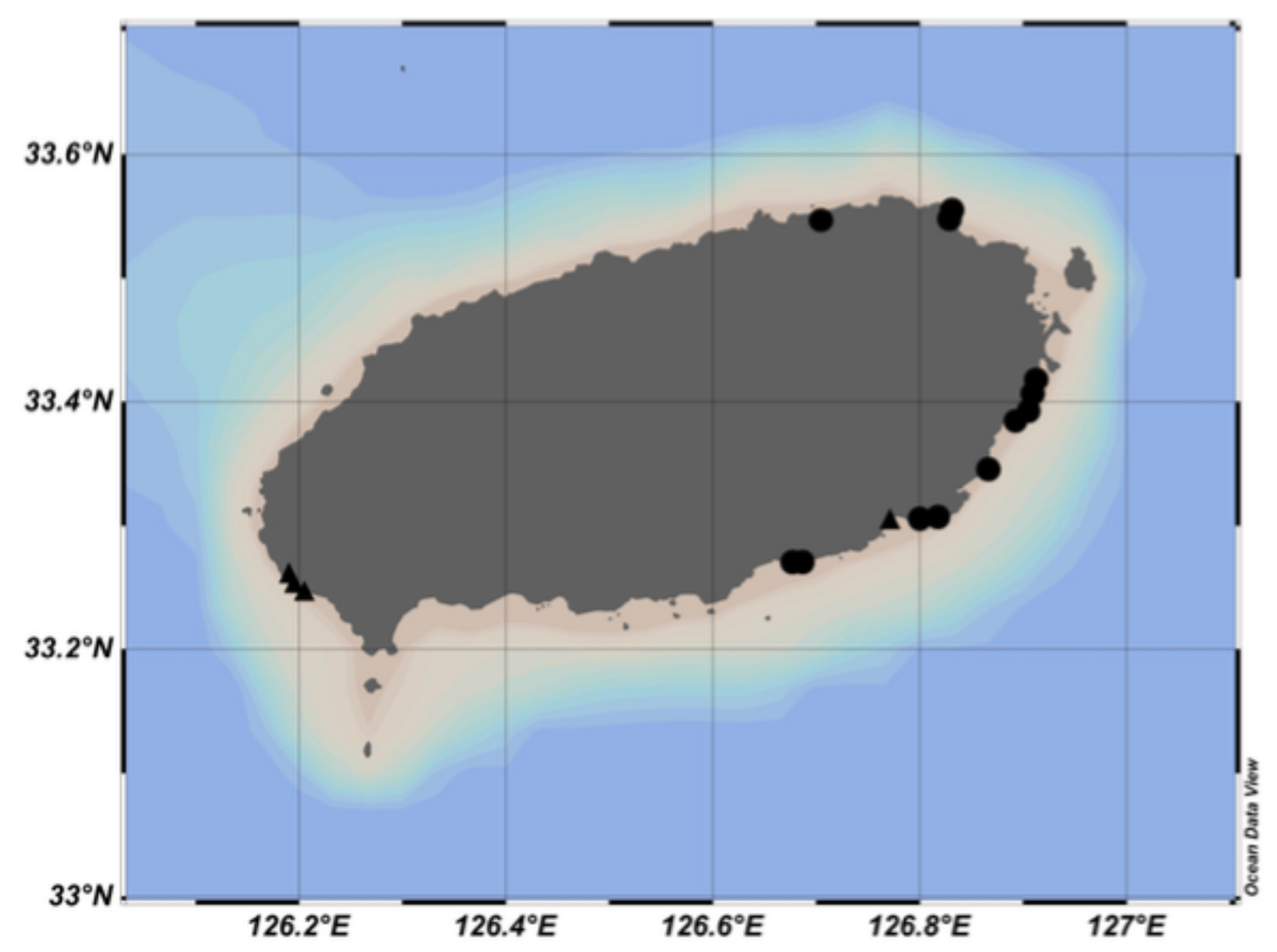

Figure 1

Map of Jeju Island in South Korea showing the location of 16 fish farms included in the study ( $\mathbf{\Delta}$ : sea water, $\bullet$ : sea water mixed with salty underground water) (Map from Ocean Data View 5.1.7 and map data source from ETOP01_2min)

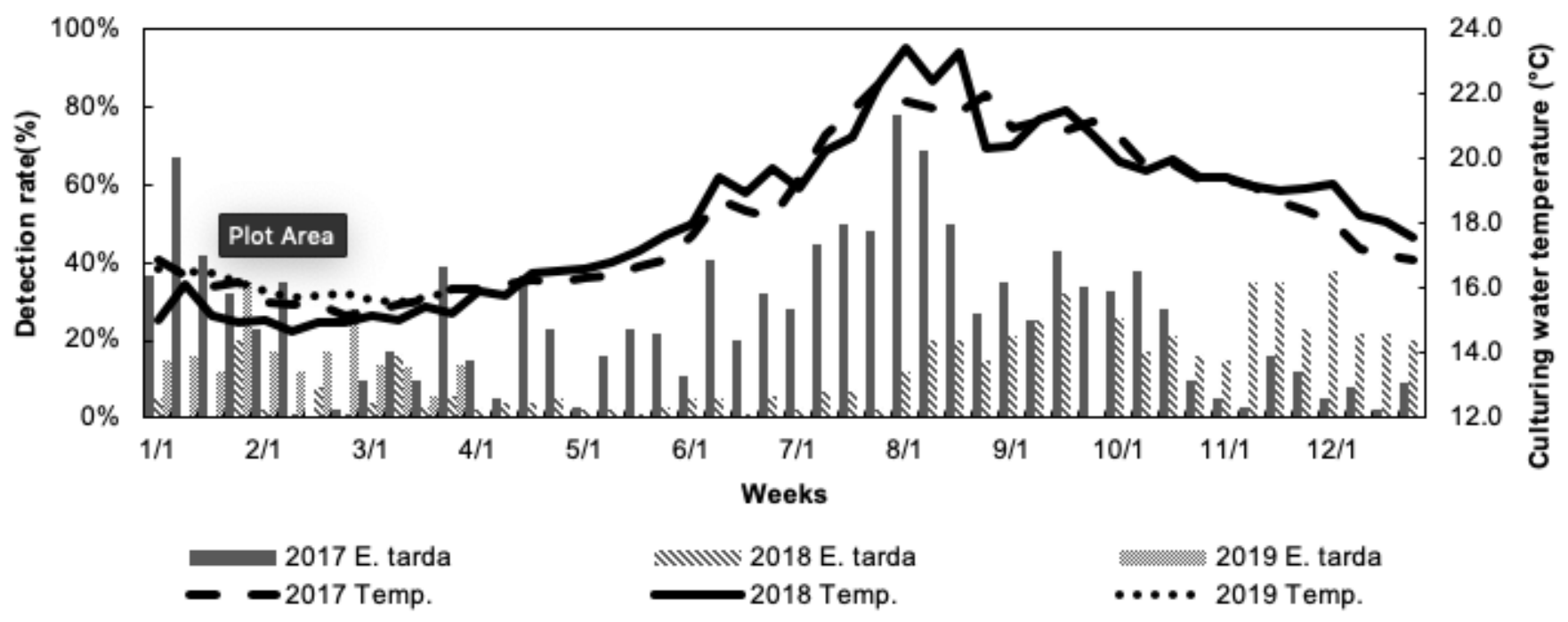

Figure 2 
Edwardsiella tarda detection rate with culturing water temperature of 2017, 2018, and 2019(March). 